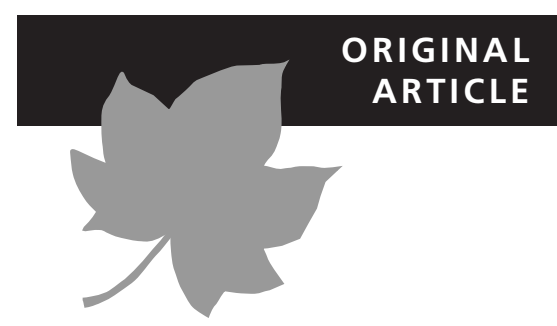

\title{
Historical biogeography of European leuciscins (Cyprinidae): evaluating the Lago Mare dispersal hypothesis
}

\author{
André Levy $^{1 \star}$, Ignacio Doadrio ${ }^{2}$ and Vítor C. Almada ${ }^{1}$
}

${ }^{1}$ Eco-Ethology Research Unit, ISPA, Lisbon, Portugal and ${ }^{2}$ Museo Nacional de Ciencias Naturales, José Gutiérrez Abascal 2, Madrid, Spain
${ }^{*}$ Correspondence: André Levy, Eco-Ethology Research Unit, ISPA, Rua Jardim do Tabaco, 34 1149-041 Lisbon, Portugal.

E-mail: andre_levy@ispa.pt

\section{ABSTRACT}

Aim To test the importance of the Lago Mare stage of the Messinian Salinity Crisis for the dispersal and diversification of European leuciscins (Cyprinidae: Leuciscinae).

Location Europe.

Methods Cytochrome $b$ sequences of European leuciscins were employed to investigate phylogenetic relationships among species, using Bayesian inference, and to estimate times of diversification, using a relaxed molecular clock. The distributions of 190 European leuciscins were compiled, and regional species compositions were compared using a taxonomic similarity index and an area cladogram.

Results Leuciscins restricted to the Iberian and Italian peninsulas and the West and South Balkan regions are phylogenetically more closely related to northern European species than to species from another southern European area. Application of a relaxed molecular clock to a Bayesian phylogeny indicates that most southern clades originated and diversified prior to the Messinian. Southern European regions are taxonomically distinct from one another, and from a more taxonomically homogeneous group of areas that includes Anatolia, East Balkans, Middle East, North Europe and West Russia.

Main conclusions The scenario of a Messinian period of dispersal of Paratethyan fauna into Mediterranean regions, via the Lago Mare, predicts a rapid period of diversification and a pattern of close association among southern European faunas. Phylogenetic relationships among leuciscins, the timing of cladogenic events, and the taxonomic similarity among geographical regions do not conform to this expectation. The depth of clades endemic to southern Europe, together with the high levels of endemism in these regions, suggests that the faunas in these regions diverged prior to the Messinian and have evolved largely in isolation from one another. Our results support a model of gradual colonization of Mediterranean regions since the Oligocene. Subsequent connections between adjacent areas may have occurred in the Messinian or Pleistocene.

\section{Keywords}

Bayesian phylogeny, Cyprinidae, freshwater dispersal routes, historical biogeography, Lago Mare, Leuciscinae, Mediterranean, Messinian Salinity Crisis.

\section{INTRODUCTION}

Phylogenetic and distribution data can be used to determine the relative importance of different geographical processes in the dispersal and diversification of taxa. Primary freshwater fish, which evolved in freshwater systems and do not withstand marine conditions, are among the taxa that most reliably reflect geographical history (Briggs, 1995), including connections 
among hydrographic basins, and the process of isolation and interconnection among rivers and lakes (Doadrio, 1988; Bermingham \& Martin, 1998).

Cyprinids colonized Europe, from Asia, in the Oligocene, when the Turgai Sea (which separated the two continents) dried out, between 30 and $35 \mathrm{Ma}$ (Banarescu, 1960, 1992; Briggs, 1995; Popov et al., 2004). Two main biogeographical scenarios have been invoked to explain their subsequent dispersal throughout Europe. The northern river-dispersal scenario (Banarescu, 1973, 1992; Almaça, 1976) postulates slow dispersal, via river captures, from northern into southern Europe, from the late Oligocene until the late Pliocene (351.7 Ma). In this scenario, the colonization of southern Europe occurred prior to the intensification of the alpine orogeny during the Miocene, which severed most freshwater connections between northern and southern European regions (Popov et al., 2004).

Bianco (1990) cast doubt on the role of river captures in explaining colonization of southern Europe, and proposed a southern sea-dispersal scenario, which would have taken place during the Lago Mare stage of the Messinian Salinity Crisis (MSC), 5 Ma (Hsü et al., 1977; Krijgsman et al., 1999). In the Messinian, the isolation of the Mediterranean from the Atlantic Ocean and the Red Sea, combined with a decrease in rainfall, led to a drop in Mediterranean sea level and increasingly hypersaline water, which would have prevented freshwater dispersal during most of the MSC. However, during the brief Lago Mare stage $(0.1 \mathrm{Myr})$, freshwater from the Sarmatic Sea (Paratethys) drained into the Mediterranean basin, and might have allowed the Paratethyan freshwater fish fauna to colonize the Mediterranean margins. The two scenarios, however, are not mutually exclusive (Doadrio \&
Carmona, 2003), and both dispersal routes could have played a consecutive role in determining extant distributions (Banarescu \& Coad, 1991).

We used distributional and phylogenetic information to assess the relative importance of the two biogeographical scenarios in the Leuciscinae, a cyprinid subfamily (sensu Howes, 1991; Nelson, 2006) that is very diverse in Europe. We dedicate particular attention to the origin of the distinct faunas in the Iberian and Italian peninsulas and the West and South Balkans (Fig. 1), herein collectively and loosely referred to as the southern peninsulas. The southern seadispersal scenario predicts that the taxonomic affinity among the ichthyofaunas of southern peninsulas is greater than that of any of these regions with northern Europe, and that divergence times estimated independently for the various clades present in the peninsulas converge upon the Lago Mare stage. In contrast, the northern river-dispersal scenario predicts that the taxonomic affinity of the ichthyofauna of each of the southern peninsulas with northern Europe is greater than the affinity that the southern peninsula faunas have among themselves, and that clades of species from these regions diverged from one another prior to the Messinian.

\section{MATERIALS AND METHODS}

We considered the alburnins and phoxinins within the Leuciscinae, and excluded gobionins, tincins and cultrinxenocyprins, in accordance with recent morphological and molecular evidence (Briolay et al., 1998; Gilles et al., 2001; Cunha et al., 2002; Liu \& Chen, 2003; Freyhof et al., 2006; Nelson, 2006; Robalo et al., 2007).
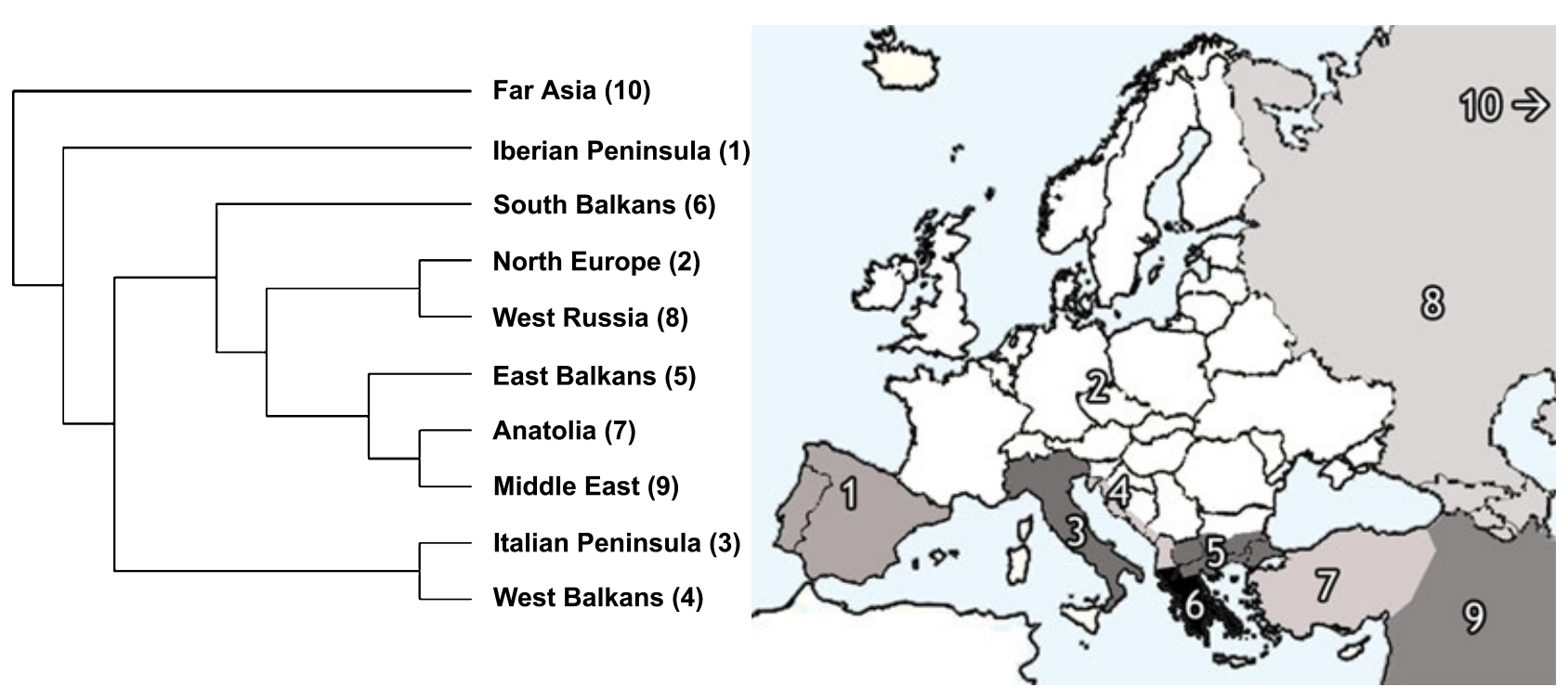

Figure 1 Area cladogram (nearest-neighbour interchange branch swapping; minimizing number of leaves added) for European leuciscins considering the following biogeographical areas: (1) Iberian Peninsula; (2) North Europe; (3) Italian Peninsula; (4) West Balkans;

(5) East Balkans; (6) South Balkans; (7) Anatolia; (8) West Russia; (9) Middle East; (10) Far East. The relationship among areas is based on similarity among taxonomic composition, using presence/absence data for 190 Euro-Asian leuciscin species. 


\section{Phylogenetic analysis}

We used the mitochondrial cytochrome $b$ gene (cyt $b$ ), the most widely sequenced DNA marker for European cyprinids, which has been shown to be informative for interrelationships among actinopterygian fishes more recent than $50 \mathrm{Myr}$ (Lydeard \& Roe, 1997). This marker has been used in studies of the relationships among Eurasian cyprinids (Briolay et al., 1998; Gilles et al., 1998; Zardoya \& Doadrio, 1999; Cunha et al., 2002), in phylogenetic studies of specific clades (Machordom \& Doadrio, 2001; Doadrio \& Carmona, 2003, 2004; Sanjur et al., 2003; Tsigenopoulos et al., 2003; Ketmaier et al., 2004; Freyhof et al., 2006; Robalo et al., 2006, 2007), and of faunas of specific regions (Zardoya \& Doadrio, 1998; Zardoya et al., 1999; Hrbek et al., 2004).

We compiled cyt $b$ sequences for all European Leuciscinae species available in GenBank, and included some North American, Middle Eastern and Asian leuciscins and other Cyprinidae, for a total of 159 sequences (see Table S1 in Supporting Information). Sequence alignment was based on the inferred amino acid sequence and edited using BioEdit (Hall, 1999).

Aligned sequences were analysed by maximum parsimony analysis (MP; heuristic searches, 10 random stepwise additions, tree bisection-reconnection branch swapping), neighbour-joining (NJ) (Saitou \& Nei, 1987), and Bayesian methods (Huelsenbeck et al., 2001). The MP and NJ analyses were performed using PAUP ${ }^{*} 4 \mathrm{~b} .10$ (Swofford, 2003), stipulating two species of Cyprininae (Carassius auratus and Cyprinus carpio) as outgroups. Branch support was tested by bootstrap analysis, with 1000 resamplings. Bayesian analysis was performed using MrBayes 3.1 (Ronquist \& Huelsenbeck, 2003), with C. auratus as the outgroup. Topologies obtained by the three methods were compared using Shimodaira-Hasegawa tests (Shimodaira \& Hasegawa, 1999), as implemented in PAUP $^{*}$, under the likelihood criterion.

Previous attempts to apply a strict molecular clock to cyt $b$ in cyprinids resulted in rejection (Zardoya \& Doadrio, 1999; Doadrio \& Carmona, 2004), leading authors to remove taxa that cause rate disparity. Rather than removing taxa from our analysis, we opted for applying Bayesian molecular dating (Rutschmann, 2005), under the assumption of a relaxed molecular clock, using PAML (Yang, 1997) and multidivtime (Thorne et al., 1998; Kishino et al., 2001). This approach accounts for heterogeneity of mutation rates among sequences. Divergence times were inferred assuming a $1.05 \%$ divergence between lineages per Myr (Dowling et al., 2002; Doadrio \& Carmona, 2004). Molecular clocks tend to underestimate divergence times that are much older than the calibration period, and to overestimate much younger divergences (Arbogast et al., 2002). However, this molecular clock was calibrated using 11 leuciscin fossils, between 15 and $0.1 \mathrm{Myr}$ old, which cover the time period most critical for our discussion, the Messinian.

\section{Biogeographical analysis}

We considered 10 biogeographical areas (Fig. 1), based in part on the areas for freshwater species defined by Banarescu (1992): (1) Iberian Peninsula; (2) North Europe (including western Europe, the Danubian basin, the British Isles and the Baltic and Fennoscandia areas); (3) Italian Peninsula; (4) West Balkans (the northern Adriatic coast of the Balkans, west of the Dinaric Alps); (5) East Balkans (the Aegean Coast of the Balkans); (6) South Balkans (the Ionian Peninsula); (7) Anatolia; (8) West Russia; (9) Middle East; (10) Far East. These areas were considered with the restricted purpose of comparing species composition of southern European areas with those of northern Europe and adjacent areas.

We compiled a presence/absence matrix for a total of 190 European leuciscins, based on information from Red Book distributions (Cabral et al., 2005; IUCN, 2006; Smith \& Darwall, 2006); online databases, including FishBase (Froese \& Pauly, 2007), Checklist of the Italian fauna (Stoch, 2003), National Fish Chart (Portugal) (Ribeiro et al., 2005), Freshwater Fishes of Iran (Coad, 2002); and complemented and amended this information with relevant primary literature and contributions from taxonomists.

Similarity among regional species composition was quantified using the taxonomic similarity index $\left(\Delta_{\mathrm{S}}\right)$ (Izsak \& Price, 2001 ), which uses presence/absence data and incorporates the average minimum taxonomic distance between any two species in different areas. Taxonomic distance can be quantified by incremental path lengths according to taxonomic rank (Clarke \& Warwick, 1999; Izsak \& Price, 2001). We calculated $\Delta_{S}$ among the 10 geographical areas using all 190 European leuciscins and discriminating four taxonomic ranks: species, genus, major clade - based on the phylogenetic analysis - and subfamily. In addition, for a subset of species, we equated taxonomic distance to the maximum likelihood distance between cyt $b$ sequences. In order to visualize taxonomic similarity among areas, we performed a multi-dimensional scaling (MDS) analysis of the similarity matrix, using statistica (Statsoft, 2003). Using these similarity indices, we tested for differences between the southern areas (areas 1, 3, 4 and 6) and northern European areas (2, 5 and 8) using a one-way analysis of similarities (ANOSIM), as implemented in PRIMER (Clarke \& Gorley, 2006). Under a Lago Mare dispersal scenario, we predicted that southern peninsulas would form a cohesive group distinct from northern Europe. To further establish the biogeographical affinities among southern peninsulas, we constructed an area cladogram based on the leuciscin phylogeny and distribution, using Component (Page, 1993).

\section{RESULTS}

\section{Phylogenetic analysis}

The Bayesian consensus tree was more resolved and showed a significantly higher likelihood than the MP and NJ trees 
(SH test, $P<0.001)$. All methods consistently revealed 12 well supported clades of European Leuciscinae (Fig. 2). Following the numeration in Zardoya et al. (1999), we will refer to these major clades as: Alburnoides (I); Telestes (II); Rutilus (III); Squalius (IV); Alburnus (V); Scardinius (VI); Tropidophoxinellus (VII); Abramis (VIII); Pachychilon (IX); Delminichthys (X); Leuciscus (XI); Pelecus (XII). Complete phylogenies for all three methods and species composition of each clade are available in Figs S1-S3.

Results from the application of the relaxed molecular clock revealed that diversification within major clades and separation between clades of Mediterranean species and their closest northern European relatives appears to be older than the Messinian (Fig. 3; Table 1). The lineage through time plot (Fig. 4) showed no evidence of a period of intense cladogenesis, particularly no signature of an increase in radiation events during the MSC (5 Ma).

\section{Biogeographical analysis}

The Mediterranean areas are relatively species-rich and have a high proportion of endemic species (Table 2). North Europe and East Balkans are low in species endemisms, but a relatively high proportion of European genera occurs in both areas. Only four areas have endemic genera: Iberian Peninsula, West and South Balkans, and Anatolia.

Taxonomic similarity indices calculated using taxonomic ranks and molecular distances were highly correlated $(r>0.99)$, indicating that the subset of taxa for which we had cyt $b$ sequences was representative of the overall diversity patterns in the group. Anatolia, East Balkans, Middle East, North Europe and West Russia were similar in taxonomic composition, and formed a cluster in the MDS graphs (Fig. 5). The Iberian and Italian peninsulas, and the West and South Balkans, appeared to be separated from each other and from this central cluster. Analysis of

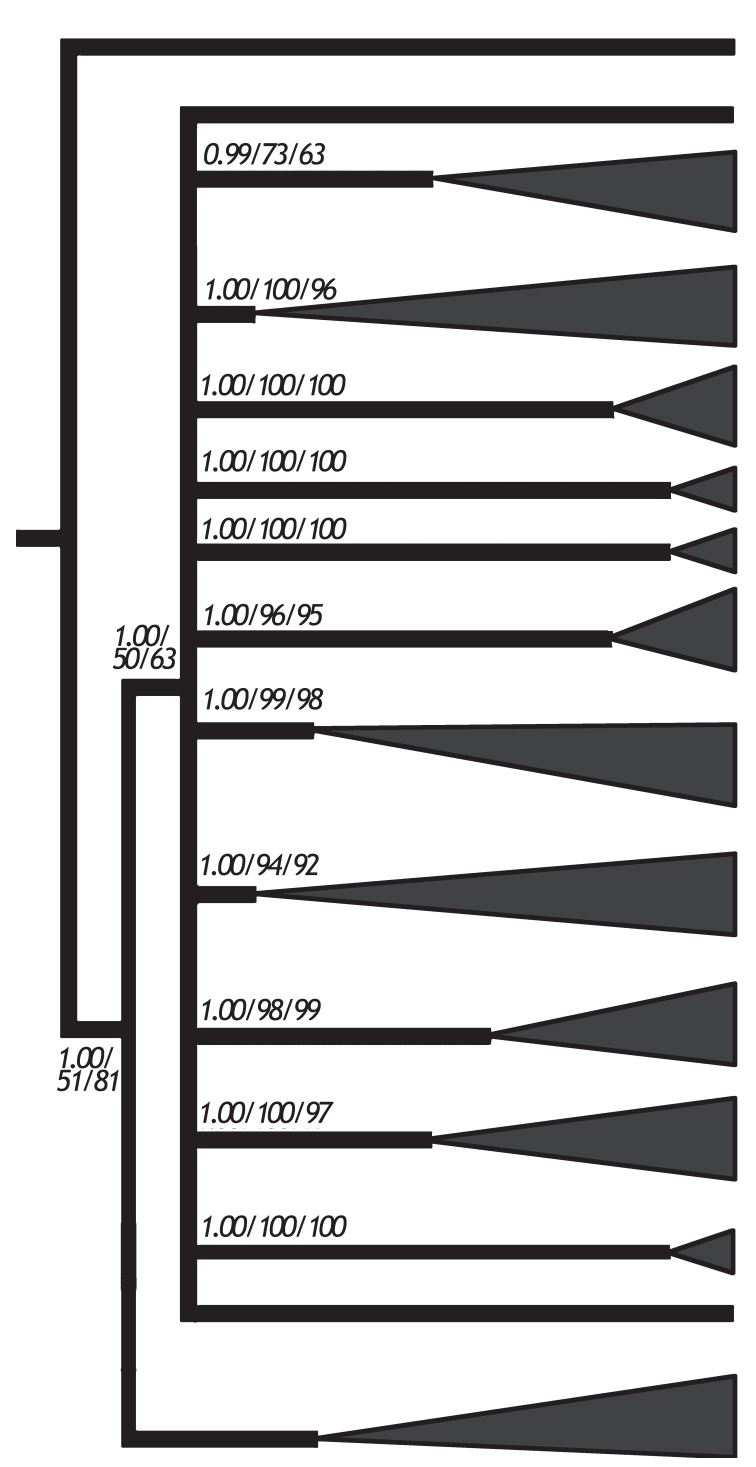

Carassius auratus Cyprininus carpio

Pelecus (XII)

Abramis (VIII)

Alburnus (V)

Scardinius (VI)

Tropidophoxinellus (VII)

Alburnoides (I)

Rutilus (III)

Telestes (II)

Squalius (IV)

Leuciscus (XI)

Delminichthys $(X)$

Pachychilon (IX)

Notemigonus crysoleucas

North American

Leuciscinae
Figure 2 Phylogenetic relationships, based on cytochrome $b$ sequences, among European Leuciscinae and North American Leuciscinae. Bayesian posterior probabilities and maximum parsimony and neighbourjoining bootstrap support values are indicated near each node. The three methods support the monophyly of the 12 major clades of European Leuciscinae discussed in the text. 


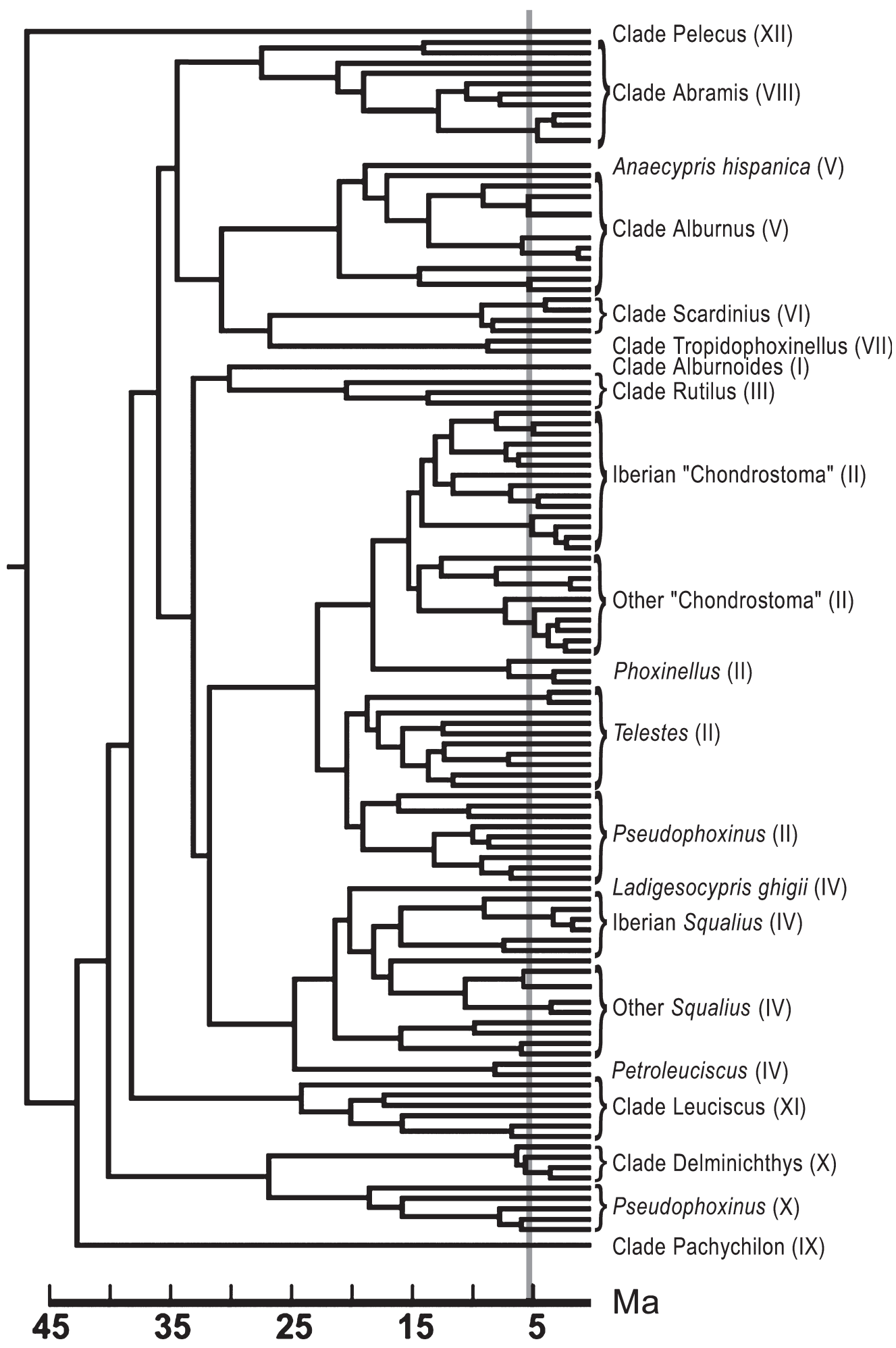

Figure 3 Bayesian topology of the European leuciscin clade, drawn to scale (time in Ma) after Bayesian molecular dating (Rutschmann, 2005), given a relaxed molecular clock, using PAML (Yang, 1997) and multidivtime (Thorne et al., 1998; Kishino et al., 2001), which allows for different evolutionary rates among lineages. Date estimates assume a molecular clock of $1 \%$ divergence between taxa $\mathrm{Myr}^{-1}$, and that European leuciscins arose after the drying of the Turgai Sea (30-35 Ma). The grey bar marks the approximate timing of the Messinian Salinity Crisis $(5.3 \mathrm{Ma})$. For clarity, species names have been replaced by summary designations, with indication of major clades (in parentheses) and some endemic subclades. All bipartitions have a posterior probability $>75 \%$. For species relationships and more detailed support values, see Fig S1. The origin of major clades and the bulk of the diversification within these clades (including several subclades endemic to southern peninsulas) is estimated to have taken place before the Messinian. 
Table 1 Estimated dates of earliest divergence time within major clades (Fig. 3) and some endemic clades, in Ma, based on a relaxed molecular clock using Bayesian molecular dating.

\begin{tabular}{lc}
\hline Clade & Ma (95\% credibility interval) \\
\hline Abramis clade (VIII) & $28.06(15.32-60.42)$ \\
Alburnus clade (V) & $21.48(10.93-46.84)$ \\
Origin of Iberian Anaecypris lineage & $19.28(9.61-42.30)$ \\
Scardinius clade (VI) & $9.29(3.86-21.63)$ \\
Tropidophoxinellus clade (VII) & $8.71(3.31-21.03)$ \\
Rutilus clade (III) & $20.75(10.40-45.86)$ \\
Telestes clade (II) & $23.36(12.48-50.29)$ \\
Origin of Iberian "Chondrostoma” & $14.42(7.13-31.61)$ \\
Squalius clade (IV) & $25.24(13.58-54.44)$ \\
Origin of Iberian Squalius & $16.19(7.89-35.84)$ \\
Leuciscus clade (XI) & $24.65(12.77-53.69)$ \\
Delminichthys (X) & $27.22(13.76-59.71)$ \\
\hline
\end{tabular}

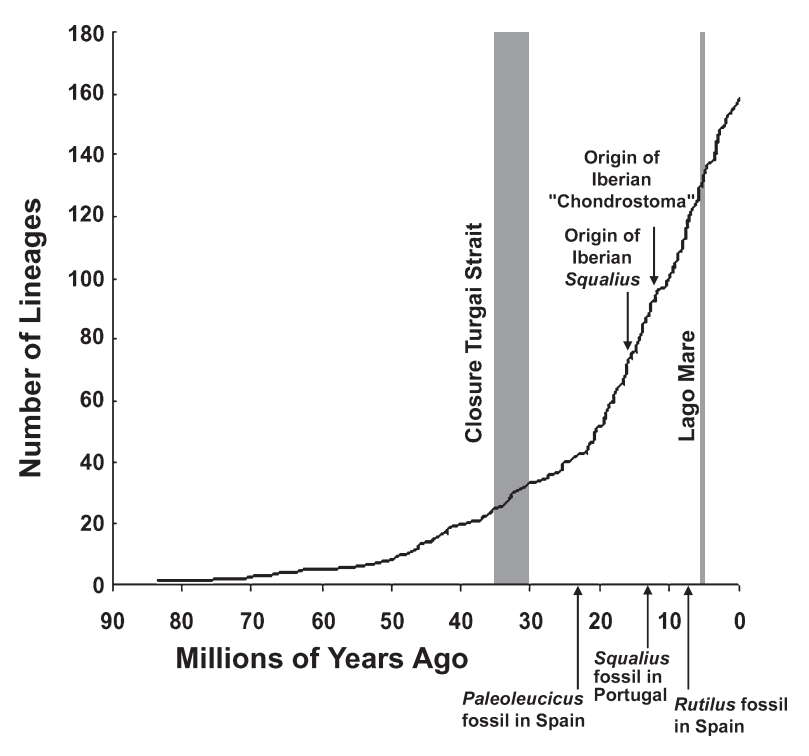

Figure 4 Lineage through time plot of Bayesian topology using molecular clock dates, illustrating the gradual accumulation of lineages through time. For comparison, we indicate the time of two major biogeographical events (the closing of the Turgai Strait, allowing the invasion of leuciscins from Asia into Europe, and the Lago Mare), the age of some pre-Messinian fossils from the Iberian Peninsula, and the estimated time of origin of subclades endemic to this region. The southern sea-dispersal hypothesis predicts a burst of diversification following the Lago Mare dispersal during the Messinian. However, the majority of lineages arose prior to the Lago Mare.

similarities was unable to detect significant differences between these areas and North Europe, East Balkans and West Russia (ANOSIM: $R=0.259 ; P=0.143$ ). The area cladogram (Fig. 1) also failed to identify a cohesive cluster formed by the southern European peninsula regions, although some associations were detectable (for example
Table 2 Species richness and percentage of endemic species for the areas considered (Fig. 1).

\begin{tabular}{|c|c|c|c|c|}
\hline \multirow[b]{2}{*}{ Location } & \multicolumn{2}{|c|}{$\begin{array}{l}\text { All European } \\
\text { leuciscins }\end{array}$} & \multicolumn{2}{|c|}{ Cyt $b$ leuciscins } \\
\hline & $\begin{array}{l}\text { No. } \\
\text { species }\end{array}$ & $\begin{array}{l}\text { Endemics } \\
(\%)\end{array}$ & $\begin{array}{l}\text { No. } \\
\text { species }\end{array}$ & $\begin{array}{l}\text { Endemics } \\
(\%)\end{array}$ \\
\hline Iberian Peninsula & 24 & 95.8 & 22 & 90.9 \\
\hline North Europe & 31 & 20.0 & 21 & 14.3 \\
\hline Italian Peninsula & 14 & 69.2 & 9 & 55.6 \\
\hline West Balkans & 37 & 83.3 & 27 & 81.5 \\
\hline East Balkans & 18 & 23.5 & 17 & 23.5 \\
\hline South Balkans & 28 & 59.3 & 21 & 52.4 \\
\hline Anatolia & 47 & 58.7 & 29 & 48.3 \\
\hline West Russia & 31 & 30.0 & 17 & 11.8 \\
\hline Middle East & 47 & 61.7 & 20 & 35.0 \\
\hline Far East & 10 & 55.6 & 5 & 40.0 \\
\hline
\end{tabular}

Calculations are based on distribution information for all European leuciscins compiled in our analysis (for the complete matrix see Table S2) and for the subset of species for which the cytochrome $b$ sequence was available (cyt $b$ matrix).

between the adjacent areas of the Italian Peninsula and West Balkans). The approach also supported a distinction among the southern faunas, particularly in the case of the Iberian Peninsula. Overall, both phylogenetic and distribution approaches consistently emphasized the uniqueness of the fauna of the southern peninsulas, the few connections among them, and the pre-Messinian diversification of each fauna.

\section{DISCUSSION}

The scenario of river-dispersal from northern Europe predicts that the faunas of the southern peninsulas diverged from each other and from that of northern Europe over an extended period (Late Oligocene to Early Miocene), whereas the southern sea-dispersal scenario (Bianco, 1990) predicts greater phylogenetic affinity among species in Mediterranean areas, with divergence times among the southern peninsular faunas concentrated in the Messinian.

\section{Was the Messinian an important period of dispersal and diversification of leuciscins?}

Application of a relaxed molecular clock suggests that clades endemic to southern European peninsulas arose several million years before the Messinian (7-5 Ma), an observation consistent with some previous molecular studies (Doadrio \& Carmona, 2003, 2004). For instance, the Iberian Squalius and "Chondrostoma" clades, as well as the Iberian endemic Anaecypris hispanica, originated between 14 and $25 \mathrm{Ma}$ (Table 1), well before the MSC, suggesting that the colonization of this peninsula occurred prior to the Lago Mare. 

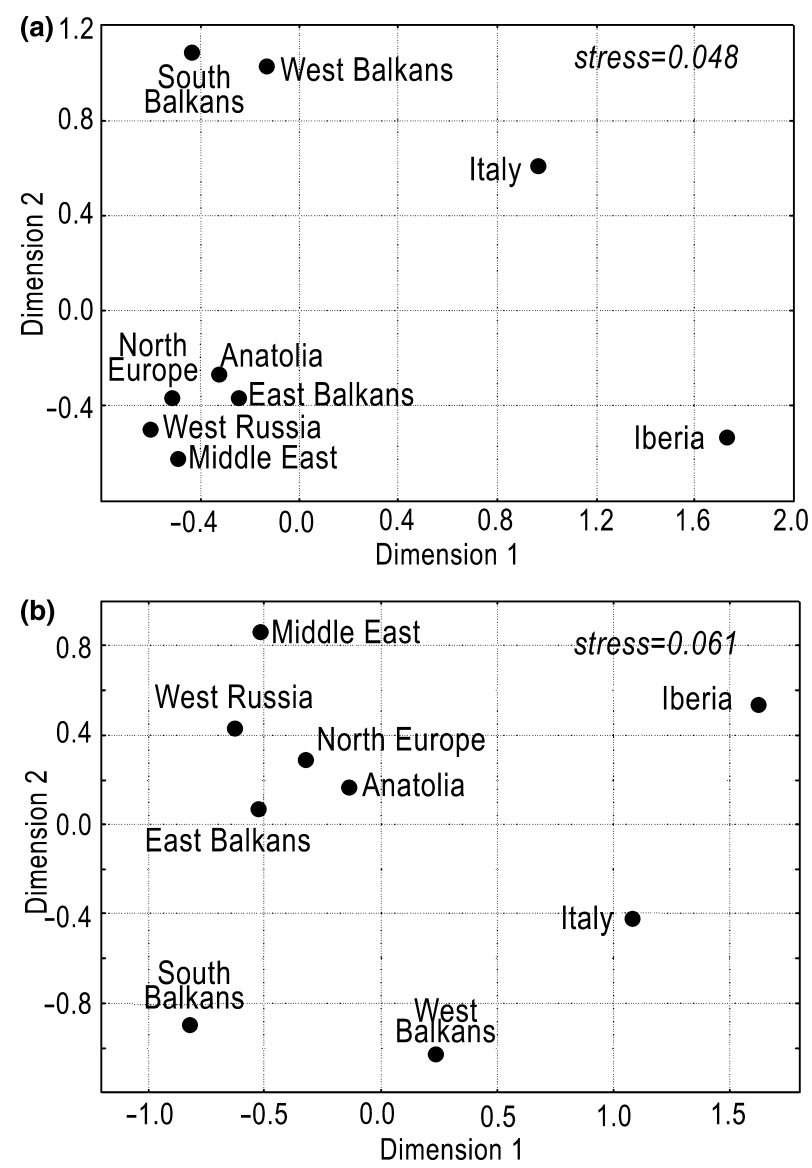

Figure 5 Taxonomic similarity among geographical areas, using multidimensional scaling. Taxonomic similarity index $\left(\Delta_{\mathrm{S}}\right)$ (Izsak \& Price, 2001), based on species presence/absence data, calculated for all European leuciscins using taxonomic rank distances between species (a), and for species used in the molecular phylogeny using maximum likelihood distances between cytochrome $b$ sequences (b).

We found no evidence for a burst of cladogenic events during the Messinian, which might be expected if the southern sea-dispersal was followed by quick diversification. Rather, we found that many endemic clades diverged and diversified before $10 \mathrm{Ma}$ (Fig. 3), and cladogenesis occurred continuously over time without an obvious modal value near the Messinian (Fig. 4).

\section{Do the southern peninsulas form a distinct biogeographical unit?}

Analysis of taxonomic similarity among geographical areas (Fig. 5) and the area cladogram (Fig. 1) revealed that southern European areas (Iberian and Italian Peninsulas and West and South Balkans) do not cluster together, as predicted by the southern sea-dispersal scenario. MDS of taxonomic similarities revealed close affinities between North Europe, West Russia, East Balkans, Anatolia and the Middle East, while each southern European area appeared to be as similar to this cluster as to other southern European areas (Fig. 5). The lack of significance in the ANOSIM, when comparing southern and northern European areas, also suggests that the former do not form a significantly distinct and homogeneous fauna.

The high level of old endemisms in the Iberian Peninsula (Table 2) and their phylogenetic affinities suggest a limited connection of this region with northern Europe early in the divergence of European leuciscins, allowing the colonization of Iberia, in the upper Oligocene, by the ancestors of only a few genera, namely Anaecypris, Squalius and a primitive "Chondrostoma". Additional connections may have occurred subsequently, during the Lago Mare or via river captures during Pleistocene glacial maxima. For instance, the divergence time between the French Parachondrostoma toxostoma and its Iberian sister species is about $2.5 \mathrm{Myr}$, suggesting a PlioPleistocenic connection between eastern Spain and southern France (Robalo et al., 2007). Trans-Adriatic exchanges between the western Balkans and eastern Italy, during the Würmian regression, may explain the co-occurrence of some species in these regions, for example Squalius cephalus or Scardinius erythrophthalmus (Bianco, 1990).

Lago Mare dispersal has also been invoked to explain the phylogenetic affinity of Iberian and African-Middle Eastern clades of the cyprinin Luciobarbus (Tsigenopoulos et al., 2003) and the cobitid Cobitis (Perdices \& Doadrio, 2001). However, Iberia and Africa were connected 18-15 Ma, allowing the dispersal of African mammals into the Iberian Peninsula (Andeweg, 2002), and once more in the Messinian with the closing of the Atlantic-Mediterranean connections (Krijgsman et al., 1999), allowing further mammal exchange 6.2 Ma (Agustí et al., 2006). Dispersal of freshwater fauna during such land mass contacts may have occurred via river captures or coastal diffusion. The chronological proximity of an AfricanEuropean land-bridge with the Lago Mare stage might make it difficult to test between the two dispersal hypotheses. However, the close affinities of north-western African Luciobarbus and Cobitis with Iberian species rather than with species from other Mediterranean areas seem to argue in favour of dispersal via land connections. This conclusion is further supported by the fact that Lago Mare conditions were more pronounced, and thus more favourable for dispersal, in the eastern Mediterranean than in the west (Meijer \& Krijgsman, 2005).

\section{Is there evidence of pre-Messinian leuciscins in southern peninsulas?}

Although scarce, the fossil record of cyprinids in the Iberian Peninsula begins in the Upper Oligocene (de la Peña, 1995), and includes several pre-Messinian fossils of Leuciscinae, for example Rutilus from the Tortonian of Spain (de la Peña, 1995), Squalius from the Serravallian (Middle Miocene) of Portugal (Gaudant, 1977), an Aquitanian (Daams, 1976) and several Tortonian fossils of Paleoleuciscus in Spain (M. Böhme, personal observation). Thus the fossil record supports colonization of the region well before the Messinian. The scarcity of pre-Messinian fossils in south-eastern Spain and in Italy may well be due to the substantial tectonic restructuring suffered by these regions prior 
to the Messinian and the submergence of much of the Italian Peninsula during the Tortonian (de la Peña, 1995).

\section{Difficulties raised by the southern sea-dispersal scenario}

The southern sea-dispersal scenario predicts concerted dispersal of many lineages across the whole Mediterranean area, during the Lago Mare, and their subsequent diversification. However, the phylogenetic and biogeographical patterns in leuciscins described above are more consistent with the colonization of southern peninsulas prior to the Messinian, and with the relative independence of their biogeographical histories.

If the Lago Mare favoured long-distance dispersal when the Paratethys drained into the Mediterranean, why do we not find Luciobarbus and other genera in intermediate regions between Greece and the Iberian Peninsula (Machordom \& Doadrio, 2001)? Why does the Italian peninsula have such a comparatively low diversity? Why are most large Mediterranean islands practically devoid of native freshwater cyprinids? Why are there so few leuciscins in northern Africa? If the Lago Mare stage played a central role in leuciscin dispersal, one would expect several clades with truly peri-Mediterranean distributions. However, among the major clades, only clade IV (Squalius) has species in all southern peninsulas.

\section{CONCLUSIONS AND OTHER DISPERSAL SCENARIOS}

The Lago Mare is unlikely to have played a major role in the initial colonization of southern peninsulas and the diversification of leuciscins. This does not rule out its possible role in short-range dispersal of some species, allowing their diffusion into adjacent locations, or in the dispersal of other freshwater taxa, particularly non-primary freshwater species that are more salt-tolerant (but see Hrbek \& Meyer, 2003).

Freshwater species may have dispersed from Russia across northern Europe, by river connections and through freshwater lakes and marshes during the lower Oligocene (Popov et al., 2004), as revealed by cyprinid fossils in France of Palaeotinca and Palaeorutilus, as early as the Chattian (Upper Oligocene) (Böhme \& Ilg, 2003). From here they could have colonized Iberia, before the Pyrenean-Alpine orogeny isolated this peninsula, in the upper Oligocene (Andeweg, 2002). This would explain why only a few lineages were capable of colonizing Iberia. From Asia, cyprinids could also have dispersed from the Middle East via north Africa, as seems to have been the case with Luciobarbus (Machordom \& Doadrio, 2001). Among leuciscins, this southern Mediterranean route along north Africa was perhaps followed only once, by the ancestor of the three leuciscins known in this area, Pseudophoxinus callensis, P. chaignoni and P. punicus (the taxonomic status of which are not well established), and played no role in the subsequent colonization of Europe by leuciscins. Thus, colonization of
Europe by leuciscins would have taken place over a broad front extending from Russia to south-eastern Europe.

Dispersal from the Far East across Russia probably accounted for the introduction of the leuciscins into the Paratethys, a vast freshwater body, and ensured not only connections between the Far East and North Europe, but also with territories in south-eastern Europe and Anatolia (Popov et al., 2004). After the disappearance of the Paratethys and its fragmentation into a number of smaller lakes and drainages, the process of diversification by vicariance could have continued on a regional scale (e.g. Bohlen et al., 2006). This would explain why each clade present in North Europe is represented by several species in the south-eastern areas, including East Balkans, Middle East and Anatolia. Subsequently, these areas were probably subject to attenuated effects of glaciations, allowing the survival of many more species in these areas than in northern Europe.

After the glaciations, the oligohaline phase of the Black Sea would have permitted new dispersals to North Europe, namely via the Danube, through waterways connecting the East Balkans and areas around the Black Sea with the more western regions of the continent (Banarescu, 1992; Kotlík \& Berrebi, 2001). Other water bodies, which passed through oligohaline phases after the last glaciation, may also have facilitated the rapid dispersal of leuciscins. For instance, the Baltic, where many cyprinids still live, may have allowed rapid dispersal to areas as far north as Scandinavia and, to the west, to what is now the North Sea where British and west European rivers converged.

More recently, some limited connections between adjacent areas may also have played a role in lineage dispersal (such as Dalmatia and Italy; France and Spain), but these could have been Pleistocenic and not necessarily Messinian (i.e. associated with the Lago Mare). Further intra-specific studies (Durand et al., 1999; Salzburger et al., 2003; Sanjur et al., 2003) will allow us to address these specific cases and the broader question of the role of southern areas as refugia. The Lago Mare does not seem, however, to have played a major role in the dispersal and diversification of European leuciscins.

\section{ACKNOWLEDGEMENTS}

We thank Jörg Freyhof for help with taxonomic and distributional information, and early access to DNA sequences. This study was funded by the Plurianual Program (Fundação para a Ciência e Tecnologia, FCT, UI\&D 331/94, partially FEDER funded). A. Levy was supported by an FCT Grant (SFRH/BPD/ 18067/2004).

\section{REFERENCES}

Agustí, J., Garcés, M. \& Krijgsman, W. (2006) Evidence for African-Iberian exchanges during the Messinian in the Spanish mammalian record. Palaeogeography, Palaeoclimatology, Palaeoecology, 238, 5-14. 
Almaça, C. (1976) Zoogeografia e especiação dos ciprinídeos da Península Ibérica. Natura, nova série, 4, 1-28.

Andeweg, B. (2002) Cenozoic tectonic evolution of the Iberian Peninsula. PhD Thesis, Vrije Universiteit Amsterdam.

Arbogast, B.S., Edwards, S.V., Wakeley, J., Beerli, P. \& Slowinski, J.B. (2002) Estimating divergence times from molecular data on phylogenetic and population genetic timescales. Annual Review of Ecology and Systematics, 33, 707-740.

Banarescu, P. (1960) Einige Fragen zur Herkunft und Verbreitung der Süsswasserfischfauna der europäisch-mediterranen Unterregion. Archiv für Hydrobiologie, 57, 16-134.

Banarescu, P. (1973) Some reconsiderations on the zoogeography of the Euro-Mediterranean freshwater fish fauna. Revue Romaine de Biologie (Zoologie), 18, 257-264.

Banarescu, P. (1992) Zoogeography of freshwaters. Vol. II. Distribution and dispersal of freshwater animals in North America and Eurasia. Aula-Verlag, Wiesbaden.

Banarescu, P. \& Coad, B.W. (1991) Cyprinids of Eurasia. Cyprinid fishes: systematics, biology and exploitation (ed. by I.J. Winfield and J.S. Nelson), pp. 127-151. Chapman \& Hall, London.

Bermingham, E. \& Martin, A.P. (1998) Comparative mtDNA phylogeography of neotropical freshwater fishes: testing shared history to infer the evolutionary landscape of lower Central America. Molecular Ecology, 7, 499-517.

Bianco, P. (1990) Potential role of the paleohistory of the Mediterranean and Paratethys basins on the early dispersal of Euro-Mediterranean freshwater fishes. Ichthyological Exploration of Freshwaters, 1, 167-184.

Bohlen, J., Perdices, A., Doadrio, I. \& Economidis, P.S. (2006) Vicariance, colonisation, and fast local speciation in Asia Minor and the Balkans as revealed from the phylogeny of spined loaches (Osteichthyes; Cobitidae). Molecular Phylogenetics and Evolution, 39, 552-561.

Böhme, M. \& Ilg, A. (2003) fosFARbase. http://www. wahre-staerke.com.

Briggs, J.C. (1995) Global biogeography. Developments in palaeontology and stratigraphy. Elsevier, Amsterdam.

Briolay, J., Galtier, N., Brito, R.M. \& Bouvet, Y. (1998) Molecular phylogeny of Cyprinidae inferred from cytochrome $b$ DNA sequences. Molecular Phylogenetics and Evolution, 9, 100-108.

Cabral, M.J., Almeida, J., Almeida, P.R., Dellinger, T., Almeida, N.F.D., Oliveira, M.E., Palmeirim, J.M., Queiroz, A.I., Rogado, L. \& Santos-Reis, M. (2005) LIVRO VERMELHO dos vertebrados de Portugal. Peixes dulciaquícolas e migradores, anfíbios, répteis, aves e mamíferos. Instituto da Conservação da Natureza, Lisboa.

Clarke, K.R. \& Gorley, R.N. (2006) PRIMER. Version 6. Primer-E, Plymouth.

Clarke, K.R. \& Warwick, R.M. (1999) The taxonomic distinctness measure of biodiversity: weighting of step lengths between hierarchical levels. Marine Ecology Progress Series, 184, 21-29.
Coad, B.W. (2002) Freshwater fishes of Iran. http://www.briancoad.com $/$ main.asp? page=titlepage $\cdot$ htm.

Cunha, C., Mesquita, N., Dowling, T.E., Gilles, A. \& Coelho, M.M. (2002) Phylogenetic relationships of Eurasian and American cyprinids using cytochrome $b$ sequences. Journal of Fish Biology, 61, 929-944.

Daams, R. (1976) Miocene rodents (Mammalia) from Cetina de Aragon (Prov. Zaragoza) and Bunol (Prov. Valencia), Spain. Proceedings of the Koninklijke Nederlandse Akademie van Wetenschappen (B), 79, 152-182.

Doadrio, I. (1988) Delimitation of areas in the Iberian Peninsula on the basis of freshwater fishes. Bonner Zoologischer Bulletin, 39, 113-128.

Doadrio, I. \& Carmona, J.A. (2003) Testing freshwater Lago Mare dispersal theory on the phylogeny relationships of Iberian cyprinid genera Chondrostoma and Squalius (Cypriniformes, Cyprinidae). Graellsia, 59, 457-473.

Doadrio, I. \& Carmona, J.A. (2004) Phylogenetic relationships and biogeography of the genus Chondrostoma inferred from mitochondrial DNA sequences. Molecular Phylogenetics and Evolution, 23, 802-815.

Dowling, T., Tibbets, C., Minckley, W. \& Smith, G. (2002) Evolutionary relationships of the plagopterins (Teleostei: Cyprinidae) from cytochrome $b$ sequences. Copeia, 2002, 665-678.

Durand, J.D., Persat, H. \& Bouvet, Y. (1999) Phylogeography and postglacial dispersion of the chub (Leuciscus cephalus) in Europe. Molecular Ecology, 8, 989-997.

Freyhof, J., Lieckfeldt, D., Bogutskaya, N.G., Pitra, C. \& Ludwig, A. (2006) Phylogenetic position of the Dalmatian genus Phoxinellus and description of the newly proposed genus Delminichthys (Teleostei: Cyprinidae). Molecular Phylogenetics and Evolution, 38, 416-425.

Froese, R. \& Pauly, D. (2007) FishBase. http://www.fishbase.org.

Gaudant, J. (1977) Contributions à la paléontologie du Miocène moyen continental du bassin du Tage. II. Observations sur les dents pharyngiennes de poissons cyprinidés-Póvoa de Santarém. Ciências da Terra (UNL), 3, 129-141.

Gilles, A., Lecointre, G., Faure, E., Chappaz, R. \& Brun, G. (1998) Mitochondrial phylogeny of the European cyprinids: implications for their systematics, reticulate evolution, and colonization time. Molecular Phylogenetics and Evolution, 10, 132-143.

Gilles, A., Lecointre, G., Miquelis, A., Loerstcher, M., Chappaz, R. \& Brun, G. (2001) Partial combination applied to phylogeny of European cyprinids using the mitochondrial control region. Molecular Phylogenetics and Evolution, 19, 22-33.

Hall, T.A. (1999) BioEdit (ver. 7.0.1): a user-friendly biological sequence alignment editor and analysis program for Windows 95/98/NT. Nucleic Acids Symposium Series, 41, 95-98.

Howes, G.J. (1991) Systematics and biogeography: an overview. Cyprinid fishes: systematics, biology and exploitation 
(ed. by I.J. Winfield and J.S. Nelson), pp. 1-33. Chapman \& Hall, London.

Hrbek, T. \& Meyer, A. (2003) Closing of the Tethys Sea and the phylogeny of Eurasian killifishes (Cyprinodontiformes: Cyprinodontidae). Journal of Evolutionary Biology, 16, 1736.

Hrbek, T., Stölting, K.N., Bardakci, F., Küçük, F., Wildekamp, R.H. \& Meyer, A. (2004) Plate tectonics and biogeographical patterns of the Pseudophoxinus (Pisces: Cypriniformes) species complex of central Anatolia, Turkey. Molecular Phylogenetics and Evolution, 32, 297-308.

Hsü, K.J., Montadert, L., Bernoulli, D., Cita, M.B., Erickson, A., Garrison, R.E., Kidd, R.B., Mèlierés, F., Müller, C. \& Wright, R. (1977) History of the Mediterranean salinity crisis. Nature, 267, 399-403.

Huelsenbeck, J.P., Ronquist, F., Nielsen, R. \& Bollback, J.P. (2001) Bayesian inference of phylogeny and its impact on evolutionary biology. Science, 294, 2310-2314.

IUCN (2006) IUCN Red List of Threatened Species. http:// www.iucnredlist.org.

Izsak, C. \& Price, A.R.G. (2001) Measuring $\beta$-diversity using a taxonomic similarity index, and its relation to spatial scale. Marine Ecology Progress Series, 215, 69-77.

Ketmaier, V., Bianco, P.G., Cobollia, M., Krivokapic, M., Caniglia, R. \& De Matthaeis, E. (2004) Molecular phylogeny of two lineages of Leuciscinae cyprinids (Telestes and Scardinius) from the peri-Mediterranean area based on cytochrome $b$ data. Molecular Phylogenetics and Evolution, 32, 1061-1071.

Kishino, H., Thorne, J.L. \& Bruno, W.J. (2001) Performance of a divergence time estimation method under a probabilistic model of rate evolution. Molecular Biology and Evolution, 18, 352-361.

Kotlík, P. \& Berrebi, P. (2001) Phylogeography of the barbel (Barbus barbus) assessed by mitochondrial DNA variation. Molecular Ecology, 10, 2177-2185.

Krijgsman, W., Hilgen, F., Raffi, I., Sierro, F. \& Wilson, D. (1999) Chronology, causes and progression of the Messinian salinity crisis. Nature, 400, 652-655.

Liu, H.Z. \& Chen, Y.J. (2003) Phylogeny of the East Asian cyprinids inferred from sequences of the mitochondrial DNA control region. Canadian Journal of Zoology, 81, 1938-1946.

Lydeard, C. \& Roe, K.J. (1997) The phylogenetic utility of the mitochondrial cytochrome $b$ gene for inferring intrarelationships of actinopterygian fishes. Molecular systematics of fishes (ed. by C.A. Stepien and T. Kocher), pp. 285-303. Academic Press, San Diego.

Machordom, A. \& Doadrio, I. (2001) Evidence of a Cenozoic Betic-Kabilian connection based on freshwater fish phylogeography (Luciobarbus, Cyprinidae). Molecular Phylogenetics and Evolution, 18, 252-263.

Meijer, P.T. \& Krijgsman, W. (2005) A quantitative analysis of the desiccation and re-filling of the Mediterranean during the Messinian Salinity Crisis. Earth and Planetary Science Letters, 240, 510-520.
Nelson, J. (2006) Fishes of the world, 4th edn. John Wiley \& Sons, New York.

Page, R.. (1993) Component, ver. 2.0. Natural History Museum, London.

de la Peña, A. (1995) Los peces terciarios de las cuencas continentales Ibéricas: Marco histórico y registro fósil conocido. Coloquios de Paleontología, 47, 25-46.

Perdices, A. \& Doadrio, I. (2001) The molecular systematics and biogeography of the European cobitids based on mitochondrial DNA sequences. Molecular Phylogenetics and Evolution, 19, 468-478.

Popov, S.V., Rögl, F., Rozanov, A.Y., Steininger, F.F., Shcherba, I.G. \& Kovac, M. (2004) Lithological-paleogeographic maps of Paratethys: 10 maps Late Eocene to Pliocene. Courier Forschungsinstitut Senckenberg, Stuttgart.

Ribeiro, F., Beldade, R., Dix, M. \& Bochechas, J. (2005) Carta piscícola Nacional. http://www.fluviatilis.com/dgf.

Robalo, J.I., Sousa-Santos, C., Levy, A. \& Almada, V.C. (2006) Molecular insights on the taxonomic position of the paternal ancestor of the Squalius alburnoides hybridogenetic complex. Molecular Phylogenetics and Evolution, 39, 276281.

Robalo, J.I., Almada, V.C., Levy, A. \& Doadrio, I. (2007) Re-examination and phylogeny of the genus Chondrostoma based on mitochondrial and nuclear data and the definition of five new genera. Molecular Phylogenetics and Evolution, 42, 362-372.

Ronquist, F. \& Huelsenbeck, J.P. (2003) MrBayes 3: Bayesian phylogenetic inference under mixed models. Bioinformatics, 19, 1572-1574.

Rutschmann, F. (2005) Bayesian molecular dating using PAML/ multidivtime. A step-by-step manual. University of Zurich, Switzerland. http://www.plant.ch.

Saitou, N. \& Nei, M. (1987) The neighbor-joining method: a new method for reconstructing phylogenetic trees. Molecular Biology and Evolution, 4, 406-425.

Salzburger, W., Brandstätter, A., Gilles, A., Parson, W., Hempel, M., Sturmbauer, C. \& Meyer, A. (2003) Phylogeography of the vairone (Leuciscus souffia, Risso 1826) in Central Europe. Molecular Ecology, 12, 2371-2386.

Sanjur, O.I., Carmona, J.A. \& Doadrio, I. (2003) Evolutionary and biogeographical patterns within Iberian populations of the genus Squalius inferred from molecular data. Molecular Phylogenetics and Evolution, 29, 20-30.

Shimodaira, H. \& Hasegawa, M. (1999) Multiple comparisons of log-likelihoods with applications to phylogenetic inference. Molecular Biology and Evolution, 16, 1114-1116.

Smith, K.G. \& Darwall, W.R.T. (2006) The status and distribution of freshwater fish endemic to the Mediterranean Basin. IUCN, Gland, Switzerland/Cambridge.

Statsoft (2003) STATISTICA (data analysis software system), ver. 6. Statsoft, Tulsa, OK. http://www.statsoft.com.

Stoch, F. (2003) Checklist of the species of the Italian fauna. http://www.faunaitalia.it/checklist. 
Swofford, D.L. (2003) PAUP* Phylogenetic analysis using parsimony ( ${ }^{*}$ and other methods). Version 4b.10. Sinauer Associates, Sunderland, MA.

Thorne, J.L., Kishino, H. \& Painter, I.S. (1998) Estimating the rate of evolution of the rate of molecular evolution. Molecular Biology and Evolution, 15, 1647-1657.

Tsigenopoulos, C.S., Durand, J.D., Unlu, E. \& Berrebi, P. (2003) Rapid radiation of the Mediterranean Luciobarbus species (Cyprinidae) after the Messinian salinity crisis of the Mediterranean Sea, inferred from mitochondrial phylogenetic analysis. Biological Journal of the Linnean Society, 80, 207-222.

Yang, Z. (1997) PAML: a program package for phylogenetic analysis by maximum likelihood. Computer Applications in Biosciences, 13, 555-556.

Zardoya, R. \& Doadrio, I. (1998) Phylogenetic relationships of Iberian cyprinids: systematic and biogeographical implications. Proceedings of the Royal Society B: Biological Sciences, 265, 1365-1372.

Zardoya, R. \& Doadrio, I. (1999) Molecular evidence on the evolutionary and biogeographical patterns of European cyprinids. Journal of Molecular Evolution, 49, 227-237.
Zardoya, R., Economidis, P.S. \& Doadrio, I. (1999) Phylogenetic relationships of Greek Cyprinidae: molecular evidence for at least two origins of the Greek Cyprinid fauna. Molecular Phylogenetics and Evolution, 13, 122-131.

\section{SUPPORTING INFORMATION}

Additional Supporting Information may be found in the online version of this article:

Table S1 List of species analysed and GenBank accession numbers of cytochrome $b$ sequences.

Table S2 Matrix of distributional data of the European leuciscin species.

Figure S1 Majority-rule consensus of Bayesian phylogenetic trees, with posterior probabilities.

Figure S2 Bootstrapped maximum parsimony tree.

Figure S3 Bootstrapped neighbour-joining tree.

Please note: Wiley-Blackwell is not responsible for the content or functionality of any supporting materials supplied by the authors. Any queries (other than missing material) should be directed to the corresponding author for the article.

\section{BIOSKETCHES}

André Levy obtained his $\mathrm{PhD}$ from the Stony Brook University on the evolution of plant resistance to multiple enemies. His research interests include species interactions, the evolution of morphology, and Mediterranean biogeography. Currently he is a post-doc working on the morphological evolution of freshwater and intertidal fish.

Ignacio Doadrio holds a position as Scientific Researcher at the National Museum of Natural Sciences in Madrid, Spain, where he develops multiple projects concerning the phylogeny, phylogeography, systematics and conservation of the ichthyofauna of Europe, Northern Africa and Central America.

Vítor C. Almada is a full professor at the Institute of Applied Psychology (ISPA) in Lisbon, Portugal, where he coordinates the EcoEthology Research Unit. His interests focus on combining genetic tools with biogeographical approaches to study the impact of Pleistocene glaciations on the ichthyofauna of the Northeastern Atlantic and Mediterranean, and to reconstruct the faunal history of the freshwaters of the Iberian Peninsula.

Editor: David Bellwood 